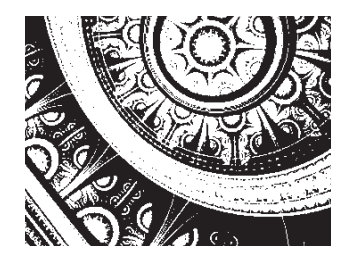

\title{
THE EFFECTIVENESS OF
}

A SCHOOL-BASED HEALTH

EDUCATION INTERVENTION

IN CHANGING SCREEN-BASED

AND PHYSICAL ACTIVITIES IN YOUNG ADOLESCENTS

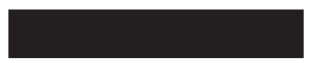

Lidija ČILIĆ BURUŠIĆ

SUVAG Polyclinic for the Rehabilitation

of Listening and Speech, Zagreb

Mia KARABEGOVIĆ

Central European University, Budapest

Dubravka KOCIJAN HERCIGONJA

School of Medicine, Zagreb

Josip BURUŠIĆ

Institute of Social Sciences Ivo Pilar, Zagreb

UDK: $373.5 .091 .3: 613$

159.922.3:613.7

613.7-053.6

Izvorni znanstveni rad

Primlieno: 11. 12. 2017.

Part of the results were presented at the EARA conference "ECER

2015", Budapest

2015.

This study examines the extent to which a comprehensive, school-based, health-education programme, based on lectures and active student participation in discussions and related project activities, can produce desirable changes in adolescents' behaviour. A quasi-experimental design, with pre- and post-intervention testing, was used in a group of adolescents $(N=858)$. Our results show that the conducted programme had modest effects. There was no difference between the pre- and post-intervention reports of time spent on screen-based activities and physical exercise, and the time spent doing physical activities was not correlated with the time they spent on sedentary activities. In this paper, we discuss various possible reasons for the ineffectiveness of such programmes in producing desired behavioural changes in young adolescents.

Keywords: health education programmes, children and young adolescents, screen-based activities, physical activities

$\square$ Josip Burušić, Institute of Social Sciences Ivo Pilar, Trg Marka Marulića 19/1, P.O. Box 277, 10001 Zagreb, Croatia.

E-mail: Josip.Burusic@pilar.hr 
DRUŠ. ISTRAŽ. ZAGREB GOD. 28 (2019), BR. 1, STR. 153-168

ČILIĆ BURUŠIĆ, L. ET AL.: THE EFFECTIVENESS...
Obesity in children and adolescents has become a prominent public health issue over the last two decades. Ogden, Carroll, Curtin, Lamb, and Flegal (2010) collected data from a group of 2- to 19-year-olds in the US and showed that almost one third of them could be considered obese, or at high risk for becoming so. In $2009-10$ around $15 \%$ of 15 -year-olds in certain European countries were reported to be obese or overweight (OECD, 2012). These results are somewhat alarming, since excessive weight can have serious negative consequences for health in adulthood, e.g. cardiovascular diseases (Baker, Olsen, \& Sørensen, 2007). Although the psychological consequences of obesity are sometimes overlooked because of the salience of life-threatening physical consequences, they should also be considered. For instance, being obese or overweight has been shown to have a detrimental effect on self-esteem and lead to poorer mental health in later life (Wang, Wild, Kipp, Kuhle, \& Veugelers, 2009).

One possible way of avoiding these negative outcomes or promoting related positive health outcomes is the adoption of comprehensive school-based programmes that inform and instruct children on how to embrace a healthier, more active lifestyle. These programmes - which can be promotionor intervention-oriented (as well as a combination of the two), and can have specific goals such as providing children with information, changing attitudes, changing behaviour, or a mix of all these - should be looked at through the crucial perspective of their effectiveness (Katz, 2009). Today's education$\mathrm{al}$ and public health policies strive to direct decision-making to reflect the best available evidence stemming from scientific research into the relevant topics, which should ultimately lead towards evidence-based practices (Brug et al., 2010). Thus, the number of comprehensive meta-analyses which sought to systematically investigate the insights of the effectiveness of such programmes related to obesity, physical activities, sedentary behaviour and related health outcomes should come as no surprise. Some studies, on the other hand, focused on the question of the validity of meta-analyses and syntheses themselves. Of the more recent attempts at these syntheses, relevant studies have been conducted by Katz (2009), Khambalia, Dickinson, Hardy, Gill, and Baur (2012); Sobol-Goldberg, Rabinowitz, and Gross (2013); Brown and Summerbell (2009); Katz, O'Connell, Njike, Yeh, and Nawaz (2008); Gori and colleagues (2017); Hynynen and colleagues (2016) and Kriemler and colleagues (2011).

Numerous school-based health education programmes start from the expectations corroborated by previous studies which report negative correlations between excessive television viewing and physical activity (Chen, Liou, \& Wu, 2008; Koezuka et al., 2006), as well as further risks regarding atten- 
DRUŠ. ISTRAŽ. ZAGREB GOD. 28 (2019), BR. 1 STR. $153-168$

ČILIĆ BURUŠIĆ, L. ET AL.: THE EFFECTIVENESS.. tional problems (Landhuis, Poulton, Welch, \& Hancox, 2007), sleep deprivation (Johnson, Cohen, Kasen, First, \& Brook, 2004) and adolescent smoking (Gidwani, Sobol, DeJong, Perrin, \& Gortmaker, 2002). Comparable results emerge in relation to computer use and playing videogames (Koezuka et al., 2006; Vandewater, Shim, \& Caplovitz, 2004), though there are reasons to believe that gender plays a moderating effect: for example, one study found that computer use only predicted obesity in girls (Kautiainen, Koivusilta, Lintonen, Virtanen, \& Rimpelä, 2005).

One of the explanations proposed for the relationship between obesity and TV-viewing has been that screen-based activities displace physical ones (Jenvey, 2007), that is, that the time children would otherwise spend being more active and playing with their peers in their free time has been substituted with screen-based forms of entertainment. On this basis, one might hypothesise that encouraging students to spend less time in front of the TV or computer and thus more time being physically active would reduce their risk of becoming obese or overweight (and vice versa). Since school-aged children spend a substantial amount of time at school (more than 170 days a year), it seems to be a good environment in which they could be educated about the risks of spending too much of their free time watching television or using computers, and by the same token, in which the benefits of a more physically active lifestyle could be promoted. Several papers have addressed this possibility by evaluating health-promoting interventions for school-aged children. Budd and Volpe (2006) reviewed 23 studies of obesity prevention interventions and concluded that the results were mixed. Some were successful in reducing participants' body mass index and television use (Robinson, 1999), and in some cases there were gender differences in programme effectiveness (Gortmaker et al., 1999). Salmon, Booth, Phongsavan, Murphy, and Timperios' (2007) systematic analysis of interventions focused on physical activity promotion summed up the effects of previous programmes by categorising them according to their most relevant characteristics, such as the environment in which they were implemented (schools, families, communities, primary care system, online) and, in the case of school-based programmes, the type of instructions (lecture-only, combined lectures and physical activities, only physical activities, "active recess", focused lectures, and many other forms which have been tested). In the subgroup of programmes carried out in schools, like the one we evaluate in this paper, only one showed positive results on the whole and - importantly - had a specific focus on a distinct population of students. More recent reviews point to only short-term gains of school-based interventions with regard to students' physical activity, and modest effect sizes, in the older 
DRUŠ. ISTRAŽ. ZAGREB GOD. 28 (2019), BR. 1, STR. 153-168

ČILIĆ BURUŠIĆ, L. ET AL.: THE EFFECTIVENESS... adolescent population (e.g. Hynynen et al., 2016). They also show that the more effective interventions include interactive modes of learning, such as feedback, goal-setting, and self-monitoring - some of which have become increasingly popular with the rise of fitness and health apps and the concept of "gamification" (Pereira, Duarte, Rebelo, \& Noriega 2014).

Given the costs of treating obesity and related diseases in adults, as well as children, it is clear that a school-based educational approach could potentially provide great benefits to students, their parents and the wider community. Since thematic interventions focused on a single topic are costly and difficult to integrate into school curricula, and personalised app-use is hard to monitor or implement at a broader level, even without the inherent privacy concerns of such interventions, there are attempts to consider whether a more general educational programme - aimed to promote the benefits of physical activities and a healthy lifestyle, among other issues - would bring about any changes in students' behaviour related to screen-based and physical activities. This is the type of educational intervention which is most commonly suggested by policy makers, though its effectiveness is questionable, and little is known about its merits in the Croatian context. Hence, the general questions we address include the following: Can school-based, advice-only programmes promoting healthy lifestyle choices influence students' overuse of media and encourage physical activity? A recent comparative systematic review and meta-analysis of 32 empirical studies (Sobol-Goldberg et al., 2013) concluded that most school-based prevention intervention programmes were at least somewhat effective, but that the effects were greater in pre-teenage children. They also concluded that comprehensive interventions were more effective than interventions based on one specific aspect of unhealthy behaviour.

In response to these findings, we additionally scrutinise the relationship between physical activity and screen-based activities in older school-age children in a sample of pre-teenagers and teenagers in order to better consider the effectiveness of school-based (preventive) intervention programmes, and use a quasi-experimental design to evaluate whether students who participated in a comprehensive school-based intervention programme changed their behaviour - time spent on exercise and screen-based activities - as a result. By addressing the aforementioned research aims, we provide additional empirical evidence about the effectiveness of school-based health programmes in the general domain of school-related health education and health promotion programmes, as well as provide specific empirical insights about the relationship of screen-based and physical activities in young adolescents in Croatia. 
The participants were fifth-grade students (modal age $=12$ years), recruited from 16 state-funded elementary schools in Croatia, which formed a convenience sample of schools. Eight of the schools were assigned to the experimental group and their students received a comprehensive health education programme; the remaining eight served as the control group and were not offered any health education programme. The majority of the 866 parents who attended the introductory meetings at schools in the experimental group $(91.9 \%, n=796)$ decided to include their children in the health education programmes; only $8.1 \%(n=70)$ declined. The total number of participants in the experimental condition was 780 ( 374 boys), but due to absences from the programme activities, absence during the initial or final wave of testing, we only used the data from participants for whom both pre- and post-intervention data were fully available without missing data, so that number was reduced to 604 . The number of participants recruited to the control group was 330 (157 boys), out of which 254 completed all the necessary questionnaires. The final sample thus comprised 858 students.

\section{Measures of Health-Related Behaviour}

Screen-based activities. Self-report data on time spent watching television, using computers and playing videogames were collected in both the initial and the follow-up questionnaires. Students were asked to indicate, on average, how much time they had spent on these activities per day over the past month, using a 0 to 3 scale $(0$ - did not engage in the activity at all; 1 less than one hour a day; 2 - two or three hours a day; 3 - more than 3 hours a day).

Physical activity. Physical activity during the past month was also self-assessed using a five-point scale where $0=$ did not engage in any sports/physical activities; 1 = engaged in sports/physical activities once or twice during the last month; 2 = engaged in sports/physical activities once a week; $3=$ engaged in sports/physical activities two or three times a week; 4 = engaged in sports/physical activities every day. No strict definition of physical activity was given, but it was exemplified in the question by activities such as riding a bike or dancing.

\section{School-Based Health Education Intervention}

The comprehensive school-based health education intervention consisted of 12 period-long lectures ( 45 minutes), class workshops and activities related to different health topics, which were delivered over half an academic year within 16 weeks. 
DRUŠ. ISTRAŽ. ZAGREB GOD. 28 (2019), BR. 1, STR. 153-168

ČILIĆ BURUŠIĆ, L. ET AL.: THE EFFECTIVENESS...

\section{Research Design}

○ TABLE 1

Pre-test and post-test nonequivalent group design cating with others; (2) similarities and differences between boys and girls; (3) how to know and respect oneself; (4) first signs of puberty; (5) eating habits, physical activity and health; (6) sources of information about sexuality; (7) friendship, crushes, popularity and role models; (8) differences between individuals; (9) violence - unacceptable behaviour; (10) recognising violent behaviour.

The organisation of the classes and the implementation of the programme was semi-flexible; teachers could decide how to best achieve the goals of the programme. Some divided the topics into separate 45-minute lectures, devoted to one topic, and some combined them into 90-minute blocks, combining two topics. The classes were held in participating schools and incorporated into the school curricula, with each topic being covered by a 45 -minute lecture, and the 12-period length of the intervention being flexible and left to the discretion of the instructors.

The instructors who delivered the lessons were school counsellors and teachers in a variety of school subjects (dominantly from STEM fields), who participated in a week long training workshops organised by the Education and Teacher Training Agency and other Croatian educational authorities before implementing the programme in their schools. They were particularly encouraged to promote student discussion and active learning. This was recognised by the students who - in their later evaluations of the programme - reported that the lessons were interesting and allowed room for student-teacher interactions, questions and more detailed explanations of the material being covered.

To address our main research questions, we used a pre- and post-test, quasi-experimental group design was used. The ideal design would have been a true experimental design, but this would have been almost impossible to implement in the standard school context. We chose then the next best option, and used a quasi-experimental design with pre- and post-intervention testing. The design for the study is presented in Table 1.

\begin{tabular}{lccc}
\hline Group & Pre-intervention & Intervention & Post-intervention \\
\hline Experimental & $\mathrm{O}_{1}$ & $\mathrm{X}_{\mathrm{T}}$ & $\mathrm{O}_{2}$ \\
Control & $\mathrm{O} 1$ & - & $\mathrm{O}_{2}$ \\
\hline
\end{tabular}

Note: $\mathrm{O} 1$ - pre-test; $\mathrm{X}_{\mathrm{T}}$ - treatment condition; $\mathrm{O}_{2}$ - post-test.

\section{Procedure}

The experimental schools were chosen via a public call for participation issued by the Croatian educational authorities, and thus constitute a convenient sample. Eight control schools 
DRUŠ. ISTRAŽ. ZAGREB GOD. 28 (2019), BR. 1 STR. 153-168

ČILIĆ BURUŠIĆ, L. ET AL.: THE EFFECTIVENESS.. were then chosen to match the geographical locations, size and other relevant sociodemographic and achievement-related characteristics of the experimental schools, where for each school in the experimental group, one school in the control group was chosen by a matching procedure. The sampling of participating students in control schools was done on the level of classes, where class units were sampled (cluster sampling). After obtaining written, informed consent for the children's participation from their parents, we used self-report questionnaires to collect data on many aspects of adolescents' health-related behaviours, as well as social and psycho-social behaviours and demographic variables. The questionnaires included items assessing screen-based and physical activities. Following the initial assessment, students in the experimental condition were included in classes which covered a variety of topics deemed important for their age group, whereas the students in the control group did not receive any intervention. The intervention was delivered over the winter term in all participating schools; individual teachers were free to choose the schedule and the way in which the topics were covered. At the end of the programme both groups completed the same questionnaires again, at roughly the same time in June.

\section{RESULTS}

\section{Relationship between Screen-Based Activities and Physical Activities}

The first question addressed was whether time spent on screen-based activities is in fact correlated with students' physical activity. Spearman's $r_{s}$ correlation coefficient was used to determine the relationship between physical exercise and the three screen-based activities investigated. The data from the pre-test assessment was used for this analysis and data from

(1) TABLE 2

Correlations between physical and screenboth groups were included as there was no reason to expect group differences at this point. All pre-test data are summarised -based activities in Table 2.

\begin{tabular}{llllll}
\hline & & $\begin{array}{c}\text { Physical } \\
\text { activity }\end{array}$ & Watching TV & $\begin{array}{c}\text { Playing } \\
\text { videogames }\end{array}$ & $\begin{array}{l}\text { Using the } \\
\text { computer }\end{array}$ \\
\hline Physical activity & $r_{s}$ & 1.000 & -0.037 & -0.047 & -0.032 \\
Watching TV & $\mathrm{N}$ & 835 & 817 & 814 & 815 \\
& $r_{s}$ & -0.037 & 1.000 & $0.296^{* *}$ & $0.247^{* *}$ \\
Playing videogames & $\mathrm{N}$ & 817 & 837 & 829 & 828 \\
& $r_{s}$ & 0.047 & $0.296^{* *}$ & 1.000 & $0.647^{* *}$ \\
Using the computer & $\mathrm{N}$ & 814 & 829 & 835 & 826 \\
& $r_{s}$ & 0.032 & $0.247^{* *}$ & $0.647^{* *}$ & 1.000 \\
& $\mathrm{~N}$ & 815 & 828 & 826 & 836 \\
\hline
\end{tabular}

**Statistically significant, $p<0.01 ; r_{S}-$ Spearman's $r$. 
DRUŠ. ISTRAŽ. ZAGREB GOD. 28 (2019), BR. 1, STR. 153-168

ČILIĆ BURUŠIĆ, L. ET AL.: THE EFFECTIVENESS...

None of the three forms of sedentary behaviour was correlated with physical activity, which suggests that participation in screen-based activities does not necessarily preclude physical exercise. However, it is interesting to note that the three forms of sedentary behaviour were correlated at the 0.01 level (two-tailed). Time spent watching TV was positively correlated with playing videogames $\left(r_{s}=0.296, p<0.01\right)$ and with spending time on the computer $\left(r_{s}=0.247, p<0.01\right)$. The strongest correlation was between playing videogames and using the computer $\left(r_{s}=0.647, p<0.01\right)$, although whether this means that students who use the computer more often also play videogames more often, or simply that the two overlap because playing videogames includes using the computer is not clear.

\section{Pre- and Post-Intervention Physical and Screen-Based Activity}

(1) TABLE 3

Comparisons of physical activities and screen-based behaviours: pre-test and post-intervention assessment; control and experimental groups, Wilcoxon and Mann-Whitney tests
Non-parametric tests were used to assess the effectiveness of the health education programme, because both physical and screen-based activities were measured on an ordinal scale. The Wilcoxon signed-ranks test was used to assess potential changes between the pre-test and post-intervention assessments; the control and experimental group results were compared with the Mann-Whitney $U$ test. These findings are summarised in Table 3.

\begin{tabular}{|c|c|c|c|c|c|c|}
\hline & & & Physical activity & Watching TV & Playing videogames & Using the computer \\
\hline \multirow[t]{4}{*}{$1-2$} & $\mathrm{E}$ & $Z$ & $-6.458^{* *}$ & -1.396 & -1.372 & -0.899 \\
\hline & & $p$ & 0.000 & 0.163 & 0.170 & 0.369 \\
\hline & $\mathrm{C}$ & $Z$ & $-2.238^{*}$ & -0.266 & -1.555 & -1.337 \\
\hline & & $p$ & 0.025 & 0.791 & 0.120 & 0.181 \\
\hline \multirow[t]{6}{*}{$E-C$} & 1 & $U$ & 68806.500 & 72224.500 & 69290.000 & 68609.500 \\
\hline & & $Z$ & -1.332 & -0.041 & -1.043 & -1.072 \\
\hline & & $p$ & 0.183 & 0.947 & 0.297 & 0.281 \\
\hline & 2 & $U$ & 71634.000 & 71551.500 & 69497.000 & 69230.000 \\
\hline & & $Z$ & -0.656 & -0.041 & -0.502 & -0.652 \\
\hline & & $p$ & 0.512 & 0.380 & 0.616 & 0.514 \\
\hline
\end{tabular}

Note: 1 - pre-test assessment, 2 - post-intervention assessment; $\mathrm{E}$ - experimental group, $\mathrm{C}$ - control group; $U$ - Mann-Whitney $U, Z$ - Wilcoxon $Z$.

There were no changes in any of the screen-based activities between the pre-test and post-intervention assessments in either group. The only difference between the two assessments was found in the physical activity variable; both groups reported more frequent physical activity in the second assessment. Further analysis showed that there was no group difference in physical activity at the post-intervention assessment 
the intervention. It is likely that a third variable, such as the changing of the seasons making it easier for students to be more active, affected students' behaviour.

\section{Gender Differences in Physical and Screen-Based Activities}

In view of previous studies which have shown gender differences in screen-based habits (as well as intervention efficiency), we additionally investigated how female and male students in our sample differed in terms of the time they spend on each activity. Our results showed that female students spent significantly more time watching television as opposed to male students $(U=75537.000, z=-2.996 ; p<0.05)$, whereas the opposite was true for playing videogames $(U=58521.000 ; z=$ - 8.455; $p<0.05)$ and using the computer $(U=59852.000 ; z=$ - 8.064; $p<0.05)$, meaning that boys reported engaging in these two activities more often. Finally, girls also reported spending significantly more time doing physical activities than boys $(U=74378.000 ; z=-3.243 ; p<0.05)$.

\section{DISCUSSION}

The principal aim of this study was to explore whether a general, advice-only health education programme could change the amount of time students spend on screen-based and physical activities. A programme that addresses multiple issues at once is not only potentially cost-effective, but would also be easier to deliver across a wide range of schools, as the vast majority lack both the infrastructure and personnel to deliver specialised interventions on all the main health topics.

Our results show that this kind of an intervention does not alter students' health-related behaviours, that is, the time they spend on screen-based activities and physical exercise. Although negative, this result is consistent with previous studies that employed a school-based, curriculum-only approach to changing students' health behaviour. Consistent with the previously mentioned review by Salmon and colleagues (2007), even the "Know Your Body" programme (Marcus, Channing Wheeler, Cullen, \& Crane, 1987), which was the only overall successful intervention, subsequently failed to be replicated (Bush et al., 1989).

There are various possible reasons for the ineffectiveness of these programmes. As Budd and Volpe (2006) noted in their overview of school-based obesity prevention initiatives, successful programmes need to start early, be repeated every couple of years and use a behaviour-change approach. One of the most well-known interventions of this kind - "Planet Health" - uses four strategies to try to reduce obesity-related habits: decreasing screen-based activities, increasing physical activi- 
DRUŠ. ISTRAŽ. ZAGREB GOD. 28 (2019), BR. 1, STR. 153-168

ČILIĆ BURUŠIĆ, L. ET AL.: THE EFFECTIVENESS... ty and altering dietary choices - and is intended to reduce the consumption of high-fat foods and increase the intake of healthy products such as fruit and vegetables (Gortmaker et al., 1999). The programme consists of lessons that are integrated into the curriculum over a two-year period, a much longer time-frame than our study, but nevertheless it was only partially successful.

Furthermore, the abovementioned intervention used techniques such as goal-setting to help participants follow through with behaviour changes, whereas the programme evaluated in this study was geared more towards providing students with information about the health issues related to sedentary behaviours and the importance of physical exercise. Earlier research on the effectiveness of various weight-loss strategies showed that, compared with other types of interventions, advice-only interventions of this kind have minimal effect on weight loss in adults (Franz et al., 2007).

In view of this, the programme we evaluated could be improved by including a component in which students are taught how to apply methods derived from behavioural treatments, such as self-monitoring, goal-setting or reinforcement (Klein et al., 2004). These methods can be used to reduce screen-based activities as well as to increase physical exercise or construct dietary plans. Students could be encouraged to keep diaries of their screen-based activities and set goals to limit the time they spend on them and to replace them with other forms of entertainment. The success of the Planet Health project suggests that it is worthwhile and possible to incorporate intervention-related lessons into the existing curriculum plans. This could be most easily achieved by including the strategies in physical education classes and putting more focus on reducing screen-based and sedentary activities as opposed to only promoting physical exercise. Furthermore, students' use of new technologies could also be used to make this process of goal-setting and progress feedback less cumbersome, as is being done in the "gamification" sphere with adults. Making the process of taking care of their health engaging and easy for students, as well as presenting it in the form of daily short-term steps in which advancement is not a far-away abstract goal to be achieved but a series of habits and goals they can easily monitor, could be a much more promising direction than trying to tailor a conventional school-based approach which will work for everyone.

On the other hand, the self-report data on the relative amounts of time participants spent on physical and screen-based activities suggest that a change in habits might not even be necessary, as participants tended to report a good balance between physical and sedentary activities. Furthermore, exer- 
DRUŠ. ISTRAŽ. ZAGREB GOD. 28 (2019), BR. 1 STR. 153-168

ČILIĆ BURUŠIĆ, L. ET AL.: THE EFFECTIVENESS.. cising was not correlated with screen-based activities, which contradicts the hypothesis that sedentary behaviours displace physical activity - one of the mechanisms suggested as being responsible for the link between sedentary activities and obesity. It also goes against some of the previous findings in this area (Koezuka et al., 2006; Chen et al., 2008). The age of our sample may have been partly responsible for the difference in results, as there is some evidence that sedentary behaviours increase during adolescence, between the ages of 11-12 years and 15-16 years (Brodersen, Steptoe, Boniface, \& Wardle, 2007).

We also found no correlation between sedentary activities and physical activity. In our sample, watching television or spending time on the computer did not preclude being physically active. Although correlations between sedentary and physical activities are often reported, Melkevik, Torsheim, Iannotti, and Wold (2010) caution that there is considerable national and regional variation in the relation and hence no universal conclusions can be drawn. Melkevik et al. (2010) also found that exceeding recommendations for screen-based activities was not correlated with physical activity in Southern and Eastern European countries, which is in line with our results. It would be interesting to investigate the characteristics of the countries where such a correlation is observed, and the potential mechanisms underlying it. Perhaps the image of a videogame-playing generation of children who never leave the house to engage with their peers is merely a stereotype, or a culturally-specific phenomenon, which doesn't have a solid basis when applied universally. It might also be the case that other activities have been displaced instead, or that children's days have become "longer" than they were in the past, thus leaving room for more activities in the day overall. The question of whether the current generation of children who spend a lot of time on screen-based activities somehow differ from the previous generations in that their screen-based activities are no longer related to a decrease in physical activities is an intriguing topic for future research in this field.

The failure of this comprehensive, school-based, health-education programme, based on an advice-only underlying principle, to produce the desired changes in young adolescents' health behaviours, suggests that more targeted interventions are needed to elicit the desired behavioural changes in health-related behaviours of adolescents. This should encourage policy makers to carefully consider all options before opting for the easy route where children's health is concerned, and should inform future attempts to design health education programmes. It is unlikely that this kind of approach can produce meaningful behavioural change, unless it is combined with techniques for teaching students to apply 
DRUŠ. ISTRAŽ. ZAGREB GOD. 28 (2019), BR. 1, STR. 153-168

ČILIĆ BURUŠIĆ, L. ET AL.: THE EFFECTIVENESS...

\section{REFERENCES}

the knowledge presented to their own lives in a practical way, such as psychological techniques used in behaviour treatments, e.g. self-monitoring and goal-setting, and monitoring their progress regularly. With this in mind, it would be wise to investigate ways of incorporating interventions aimed at reducing sedentary behaviours into the existing school curriculum, rather than conducting costly one-off programmes which do not focus on any particular area as much to yield satisfactory benefits and justify their implementation.

We would also caution against basing policy on results that were not obtained in the region at which the policy is aimed. Global health concerns - especially those about children's health - are of great importance. However, generalising from results obtained in other cultures can result in efforts being diverted from the areas in which they are truly necessary to those where they might be redundant. This highlights the importance of evaluating effectiveness in the field of health-related programmes, especially in the educational context.

As Brug and colleagues (2010) suggest, health education and health promotion interventions are important programmes, but are often carried out without formal evidence-based registration or formal guidance, as the authors demonstrated in the case of the Netherlands, where similar to many other countries, institutions specifically dealing with the fields exist but are under-used. Despite the many guidelines, instructions and examples of good practices (e.g., Campbell et al., 2000; Craig et al., 2008), the current state of the art points to the need for developing a more comprehensive evaluation and recognition system in the health education and health promotion interventions domain, which would further formalise the issues of quality assurance and control, an activity which has been ongoing in the Netherlands since 2008, but is as of yet non-existent in many countries, including Croatia.

Baker, J. L., Olsen, L. W., \& Sørensen, T. I. (2007). Childhood body-mass index and the risk of coronary heart disease in adulthood. New England Journal of Medicine, 357(23), 2329-2337. https://doi.org/10.1056/ NEJMoa072515

Brodersen, N. H., Steptoe, A., Boniface, D. R., \& Wardle, J. (2007). Trends in physical activity and sedentary behaviour in adolescence: Ethnic and socioeconomic differences. British Journal of Sports Medicine, 41(3), 140-144. https://doi.org/10.1136/bjsm.2006.031138

Brown, T., \& Summerbell, C. (2009). Systematic review of school-based interventions that focus on changing dietary intake and physical activity levels to prevent childhood obesity: An update to the obesity guidance produced by the National Institute for Health and Clinical Excellence. Obesity Reviews, 10(1), 110-141. https://doi.org/ 10.1111/j.1467-789X.2008.00515.x 
DRUŠ. ISTRAŽ. ZAGREB GOD. 28 (2019), BR. 1 STR. 153-168

ČILIĆ BURUŠIĆ, L. ET AL.: THE EFFECTIVENESS..
Brug, J., van Dale, D., Lanting, L., Kremers, S., Veenhof, C., Leurs, M., van Yperen, T., \& Kok, G. (2010). Towards evidence-based, quality-controlled health promotion: The Dutch recognition system for health promotion interventions. Health Education Research, 25(6), 1100-1106. https://doi.org/10.1093/her/cyq046

Budd, G. M., \& Volpe, S. L. (2006). School-based obesity prevention: Research, challenges, and recommendations. Journal of School Health 76(10), 485-495. https://doi.org/10.1111/j.1746-1561.2006.00149.x

Bush, P. J., Zuckerman, A. E., Theiss, P. K., Taggart, V. S., Horowitz, C., Sheridan, M. J., \& Walter, H. J. (1989). Cardiovascular risk factor prevention in black schoolchildren: Two-year results of the "Know Your Body" program. American Journal of Epidemiology, 129(3), 466-482. https://doi.org/10.1093/oxfordjournals.aje.a115158

Campbell, M., Fitzpatrick, R., Haines, A., Kinmonth, A. L., Sandercock, P., Spiegelhalter, D., \& Tyrer, P. (2000). Framework for design and evaluation of complex interventions to improve health. BMJ, 321(7262), 694-696. https://doi.org/10.1136/bmj.321.7262.694

Chen, M., Liou, Y., \& Wu, J. (2008). The relationship between TV/computer time and adolescents' health-promoting behavior: A secondary data analysis. Journal of Nursing Research 16(1), 75-84. https://doi. org/10.1097/01.JNR.0000387292.99300.92

Craig, P., Dieppe, P., Macintyre, S., Michie, S., Nazareth, I., \& Petticrew, M. (2008). Developing and evaluating complex interventions: The new Medical Research Council guidance. BMJ, 337, a1655. https://doi.org/ 10.1136/bmj.a1655

Franz, M. J., VanWormer, J. J., Crain, A. L., Boucher, J. L., Histon, T., Caplan, W., Bowman, J. D., \& Pronk, N. P. (2007). Weight-loss outcomes: A systematic review and meta-analysis of weight-loss clinical trials with a minimum 1-year follow-up. Journal of the American Dietetic Association, 107(10), 1755-1767. https://doi.org/10.1016/j.jada.2007.07.017

Gidwani, P. P., Sobol, A., DeJong, W., Perrin, J. M., \& Gortmaker, S. L. (2002). Television viewing and initiation of smoking among youth. Pediatrics, 110(3), 505-508. https://doi.org/10.1542/peds.110.3.505

Gori, D., Guaraldi, F., Cinocca, S., Moser, G., Rucci, P., \& Fantini, M. P. (2017). Effectiveness of educational and lifestyle interventions to prevent pediatric obesity: Systematic review and meta-analyses of randomized and non-randomized controlled trials. Obesity Science $\mathcal{E}$ Practice, 3(3), 235-248. https://doi.org/10.1002/osp4.111

Gortmaker, S. L., Peterson, K., Wiecha, J., Sobol, A. M., Dixit, S., Fox, M. K., \& Laird, N. (1999). Reducing obesity via a school-based interdisciplinary intervention among youth: Planet Health. Archives of Pediatrics \& Adolescent Medicine, 153(4), 409-418. https://doi.org/10. 1001/archpedi.153.4.409

Hynynen, S. T., van Stralen, M. M., Sniehotta, F. F., Araújo-Soares, V., Hardeman, W., Chinapaw, M. J., Vasankari, T., \& Hankonen, N. (2016). A systematic review of school-based interventions targeting physical activity and sedentary behaviour among older adolescents. International Review of Sport and Exercise Psychology, 9(1), 22-44. https://doi.org/10. 1080/1750984X.2015.1081706 
DRUŠ. ISTRAŽ. ZAGREB GOD. 28 (2019), BR. 1, STR. 153-168

ČILIĆ BURUŠIĆ, L. ET AL.: THE EFFECTIVENESS...
Jenvey, V. B. (2007). The relationship between television viewing and obesity in young children: A review of existing explanations. Early Child Development and Care, 177(8), 809-820. https://doi.org/10.1080/ 03004430601119851

Johnson, J. G., Cohen, P., Kasen, S., First, M. B., \& Brook, J. S. (2004). Association between television viewing and sleep problems during adolescence and early adulthood. Archives of Pediatrics $\mathcal{E}$ Adolescent Medicine, 158(6), 562-568. https://doi.org/10.1001/archpedi.158.6.562

Katz, D. L. (2009). School-based interventions for health promotion and weight control: Not just waiting on the world to change. Annual Review of Public Health, 30, 253-272. https://doi.org/10.1146/annurev. publhealth.031308.100307

Katz, D. L., O'Connell, M., Njike, V. Y., Yeh, M. C., \& Nawaz, H. (2008). Strategies for the prevention and control of obesity in the school setting: Systematic review and meta-analysis. International Journal of Obesity, 32(12), 1780-1789. https://doi.org/10.1038/ijo.2008.158

Kautiainen, S., Koivusilta, L., Lintonen, T., Virtanen, S. M., \& Rimpelä, A. (2005). Use of information and communication technology and prevalence of overweight and obesity among adolescents. International Journal of Obesity, 29(8), 925-933. https://doi.org/10.1038/sj.ijo. 0802994

Khambalia, A. Z., Dickinson, S., Hardy, L. L., Gill, T. A., \& Baur, L. A. (2012). A synthesis of existing systematic reviews and meta-analyses of school-based behavioural interventions for controlling and preventing obesity. Obesity Reviews, 13(3), 214-233. https://doi.org/10. 1111/j.1467-789X.2011.00947.x

Klein, S., Burke, L. E., Bray, G. A., Blair, S., Allison, D. B., Pi-Sunyer, X., Hong, Y., \& Eckel, R. H. (2004). Clinical implications of obesity with specific focus on cardiovascular disease. A statement for professionals from the American Heart Association Council on Nutrition, Physical Activity, and Metabolism: Endorsed by the American College of Cardiology Foundation. Circulation, 110(18), 2952-2967. https://doi.org/ 10.1161/01.CIR.0000145546.97738.1E

Koezuka, N., Koo, M., Allison, K. R., Adlaf, E. M., Dwyer, J. J., Faulkner, G., \& Goodman, J. (2006). The relationship between sedentary activities and physical inactivity among adolescents: Results from the Canadian Community Health Survey. Journal of Adolescent Health, 39(4), 515-522. https://doi.org/10.1016/j.jadohealth.2006.02.005

Kriemler, S., Meyer, U., Martin, E., van Sluijs, E. M., Andersen, L. B., \& Martin, B. W. (2011). Effect of school-based interventions on physical activity and fitness in children and adolescents: A review of reviews and systematic update. British Journal of Sports Medicine, 45(11), 923-930. https://doi.org/10.1136/bjsports-2011-090186

Landhuis, C. E., Poulton, R., Welch, D., \& Hancox, R. J. (2007). Does childhood television viewing lead to attention problems in adolescence? Results from a prospective longitudinal study. Pediatrics, 120(3), 532-537. https://doi.org/10.1542/peds.2007-0978

Marcus, A. C., Channing Wheeler, R., Cullen, J. W., \& Crane, L. A. (1987). Quasi-experimental evaluation of the Los Angeles Know Your Body 
DRUŠ. ISTRAŽ. ZAGREB GOD. 28 (2019), BR. 1 STR. 153-168

ČILIĆ BURUŠIĆ, L. ET AL.: THE EFFECTIVENESS.. program: Knowledge, beliefs, and self-reported behaviors. Preventive Medicine, 16(6), 803-815. https://doi.org/10.1016/0091-7435(87)90020-X

Melkevik, O., Torsheim, T., Iannotti, R. J., \& Wold, B. (2010). Is spending time in screen-based sedentary behaviors associated with less physical activity: A cross national investigation. International Journal of Behavioral Nutrition and Physical Activity, 7(1), 1-10. https://doi.org/10. 1186/1479-5868-7-46

OECD (2012). Overweight and obesity among children. In Health at a Glance: Europe 2012. OECD Publishing.

Ogden, C. L., Carroll, M. D., Curtin, L. R., Lamb, M. M., \& Flegal, K. M. (2010). Prevalence of high body mass index in US children and adolescents, 2007-2008. The Journal of the American Medical Association, 303(3), 242-249. https://doi.org/10.1001/jama.2009.2012

Pereira, P., Duarte, E., Rebelo, F., \& Noriega, P. (2014, June). A review of gamification for health-related contexts. In International conference of design, user experience, and usability (pp. 742-753). Cham: Springer. https://doi.org/10.1007/978-3-319-07626-3_70

Robinson, T. N. (1999). Reducing children's television viewing to prevent obesity: A randomized controlled trial. The Journal of the American Medical Association, 282(16), 1561-1567. https://doi.org/10.1001/ jama.282.16.1561

Salmon, J., Booth, M. L., Phongsavan, P., Murphy, N., \& Timperio, A. (2007). Promoting physical activity participation among children and adolescents. Epidemiologic Reviews, 29, 144-59. https://doi.org/10.1093/ epirev/mxm010

Sobol-Goldberg, S., Rabinowitz, J., \& Gross, R. (2013). School-based obesity prevention programs: A meta-analysis of randomized controlled trials. Obesity, 21(12), 2422-2428. https://doi.org/10.1002/oby.20515

Vandewater, E. A., Shim, M. S., \& Caplovitz, A. G. (2004). Linking obesity and activity level with children's television and video game use. Journal of Adolescence, 27(1), 71-85. https://doi.org/10.1016/j.adolescence. 2003.10.003

Wang, F., Wild, T. C., Kipp, W., Kuhle, S., \& Veugelers, P. J. (2009). The influence of childhood obesity on the development of self-esteem. Health Reports, 20(2), 21-27. 
DRUŠ. ISTRAŽ. ZAGREB GOD. 28 (2019), BR. 1, STR. 153-168

ČILIĆ BURUŠIĆ, L. ET AL.: THE EFFECTIVENESS...
Učinkovitost zdravstveno-obrazovne intervencije u školskom okruženju u mijenjanju fizičkih aktivnosti mlađih adolescenata i aktivnosti koje obavljaju pred zaslonima

Lidija ČILIĆ BURUŠıĆ

Poliklinika za rehabilitaciju slušanja i govora SUVAG, Zagreb

Mia KARABEGOVIĆ

Srednjoeuropsko sveučilište (CEU), Budimpešta

Dubravka KOCIJAN HERCIGONJA

Medicinski fakultet, Zagreb

Josip BURUŠIĆ

Institut društvenih znanosti Ivo Pilar, Zagreb

$U$ radu se razmatra $u$ kojoi mieri sveobuhvatni program zdravstvenog odgoja koji se provodi u školskom okruženju, a koji se oslanja na predavanja, učeničke rasprave i povezane projektne aktivnosti, može pridonijeti željenim promjenama u ponašanju mladih. Rezultati istraživanja (primjenom kvazieksperimentalnog istraživačkog nacrta s testiranjem prije i nakon provođenja programa na uzorku od 858 adolescenata) pokazuju da ovakvi programi zdravstvenog odgoja imaju skroman učinak. Nisu utvrđene statistički značajne razlike u količini vremena koju su adolescenti posvećivali aktivnostima što se provode na zaslonu u odnosu na fizičke aktivnosti prije i nakon sudjelovanja u programu, niti je vrijeme provedeno $u$ fizičkim aktivnostima adolescenata bilo povezano s količinom vremena utrošenog na sjedilačke aktivnosti. U radu su pružena moguća objašnjenja zbog čega su ovakvi zdravstveni programi, koji se temelje primarno na predavanjima, raspravama i savjetima, neučinkoviti u mijenjaju ponašanja adolescenata.

Ključne riječi: programi zdravstvenog odgoja, djeca i mlađi adolescenti, aktivnosti pred zaslonom, fizičke aktivnosti

\section{c) (i) $\$$}

Međunarodna licenca / International License: Imenovanje-Nekomercijalno/ Attribution-NonCommercial 